\title{
IDENTIFICATION RADIOACTIVE WASTE AND TREATMENT OF HAZARDOUS SUBSTANCES IN KOSOVO
}

\author{
Besire CENA ${ }^{1, *}$ \\ ${ }^{1}$ University of Mitrovica "Isa Boletini”, Faculty of Food Tehnology, \\ Str.Ukshin Kovaqica, Mitrovica 40000, Kosovo
}

\begin{abstract}
Identification of radioactive waste is a process first hand regarding the effectiveness and cost management. Radioactive sources and hazardous substances are widely used in agriculture, industry, medicine, and various research fields in our country. Their safe identification and treatment is a current problem for Kosovo, while this problem is given special attention on a global scale. This is in the national interest because in increased risk, degradation of the physical integrity of resources, and loss of control. This scientific paper occupies an important place in modern methods of treatment of this waste.
\end{abstract}

Keywords: hazardous substances; radioactive waste; environmental protection.

\section{Introduction}

The fact that during the second half of the last century in Kosovo were made from different factories, which generate many industrial chemical residues actually quite dangerous as well as the fact that at that time it did not work at all or working very little treatment and management of these hazardous wastes in our country in general and in particular the city of Mitrovica in the region list is the most contaminated (contamination) in Europe [1]. Radioactive waste can contain significant amounts of different radio nuclei, which represent a serious potential risk to the public and the environment if they are not safely managed. By applying good work practices for the treatment of radioactive waste, significant reductions in the volume of radioactive waste can be achieved, while their total elimination is impossible. It is necessary to respect the basic principles of radiation safety during the treatment of radioactive waste as well as the existence in place of an appropriate legislative framework and a regulatory supervisory body with the necessary qualification. From the point of view of radioactive waste safety, a distinction is made between wastes containing radioactive nuclei with half-life periods shorter than 100 days (Tc-99m, J-131), for waste with half-life periods shorter than 40 years (Co-57, Co-60, Eu-152, Eu-154, Cs-137) and waste containing radionuclides with a very long half-life (several hundred years, such as Am-241) [4].

Exploiting 30 milion tons of ore from the mines of lead and zinc in Trepca and their processing as final output shows a very clear picture and what type of hazardous waste left behind unfortunately still today continue to deal with these residues. Great riches underground in northern and central Kosovo, as well as other options, make it possible that in this part of the political composition to develop a comprehensive industrial activity, leaving behind millions of tons of hazardous waste land treatment today is extremely challenging and affordable for our economic opportunities [2]. A battery factory in Gjilane, Peja industrial battery factory, and a host of other factories that were part of the giant Trepca was made a strong arm of Kosovo's economic development but on the other hand, had left behind thousands of tons of hazardous 
wastes which are now seeking treatment and serious approach treatment [6]. When we add to all these hundreds of tons of expired medicines show that indeed Kosovo will have long-term problems regarding hazardous substances and their overall treatment process [3].

\section{Methodology of production}

The International Atomic Energy Agency adheres to the principle of placing every radioactive source in complete control from the moment it begins to be used for a specific purpose until it is safely disposed of as hazardous waste. On the other hand, mismanagement has resulted in Kosovo and other countries in the region having an amount of so-called "orphan resources, ie resources that have been lost and as a result have no owners, but which may be hidden or not hidden in unknown places.

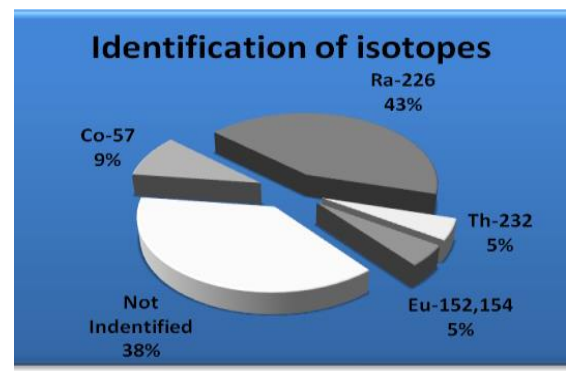

Fig. 1. Identification of some radioactive waste in Kosovo

According to some research and statistical reports that are made by the Ministry of Environment Agency and the joint work team between KSF ( Force Kosovo Security ) and all multinational brigades peacekeeping forces in Kosovo, the number and amount of hazardous substances are extremely large in relation to the territory and the number of people facing Kosovo [3]. Treatment of hazardous substances in Kosovo began after 2000, but not with an intensity that would be needed. In addition to the identification of a considerable amount of hazardous substances is repackage and forgive destroyed the excellent work that has KSF and international peacekeeping forces in Kosovo [3]. We will mention only a few which are worth emphasizing as projects that can rightfully be classified as capital projects that have taken place in our country. Projects are carried out between the Ministry of Environment, KFOR, and the management of the companies which have been those products. During that period of time with the right to have affected the process of minimizing risk. One of them has been as follows:

- Repackage a quantity of Americium in Trepca and its conservation, professional treatment done and continues to do all the time that substances.

- $\quad$ Repackage of Calcium hypochlorite in the regional water supply company in Mitrovica.

- Destroying hydrazines the amount of which has been no less than 74 power in the event of any possible accident would be catastrophic consequences for the entire industrial complex Trepca and surroundings.

- $\quad$ Repackage of more than 420 tons of various compounds in the factory in Gjilan batteries as a result of this work has been made possible their sales abroad.

\section{Material and methodology of research}

The process of addressing these dangerous substances country level requires our institutions to think seriously bout the construction of a landfill for the disposal of all hazardous 
substances where it would become possible conservation treatment and their destruction by professional people and understand scientific criteria [4].

Table 1. Data on the treatment of certain hazardous substances

\begin{tabular}{llcll}
\hline No. & Type of treatment & Name of product & Quantity & \multicolumn{1}{c}{ Place } \\
\hline 1. & Ripackage & Americium & & Flotacion in First tunnel, Mitrovica \\
2. & Ripackage & Calcium hypochlorite & $\mathbf{1 . 2}$ ton & Regional water supply, Mitrovica \\
3 & Ripackage & Mixed compounds & $\mathbf{4 2 0}$ ton & Battery factory,Gjilan \\
4. & Disposal or destruction & Hidrazina & $\mathbf{2 1 0 0 ~ l}$. & Peak Picel, Mitrovica \\
\hline
\end{tabular}

Table 2. Measurement of three radioactive sources in the first tunnel Trepca

\begin{tabular}{|c|c|c|c|}
\hline & to entry & $\begin{array}{l}\text { distance from the source, } \\
1.5 \mathrm{~m}\end{array}$ & $\begin{array}{l}\text { distance from the source, } \\
2 \mathrm{~cm}\end{array}$ \\
\hline & $0.08 \mu \mathrm{sv} / \mathrm{h}$ & & \\
\hline The first source & & $0.08 \mu \mathrm{sv} / \mathrm{h}$ & $0.09 \mu \mathrm{sv} / \mathrm{h}$ \\
\hline The second source & & $0.09 \mu \mathrm{sv} / \mathrm{h}$ & $0.11 \mu \mathrm{sv} / \mathrm{h}$ \\
\hline The third source & & $6.13 \mu \mathrm{sv} / \mathrm{h}$ & $7.14 \mu \mathrm{sv} / \mathrm{h}$ \\
\hline
\end{tabular}

The dangerous substances treatment process is an extremely difficult process, which requires significant resources, in terms of professional knowledge, time, willingness, and desire to do so. Repackaging of hazardous substances is undoubtedly one of the best forms regarding current treatment in Kosovo since our country still faces an uncertainty that should be done with some jam substances dangerous in fact the possibility of their destruction does not exist and considering the fact that in Kosovo there is not a place for handling hazardous substances landfills where they can be analyzed physic-chemical and disposal options or their treatment on other forms, or even prepare them up for sale if such a thing possible [3]. But to do so should be their repackaging under the conditions and standards required by the guidelines. Lately, repackage as a rule hazardous substances treatment in our country has started to become a perceptible form in terms of handling hazardous ingredients In 2007 the Kosovo government had ordered the Minister of Environment and Spatial Planning to find a location where it will build a landfill for the disposal of all scale hazardous matter, a country which after a joint work between the Ministry and KFOR is finally set for the location where it will be built for the treatment of landfill all hazardous substances including radioactive substances in Kosovo there is a considerable number of them. Always referring to official information issued after the meeting of the working group of the institutions mentioned above [2]. Another problem that has led to the situation that we have in terms of treatment and monitoring of hazardous substances nationwide is the process of privatization, in which case many factories or companies have changed the action neglecting a large number of without carefully hazardous ingredients.

\section{Conclusions}

Based on those that have been elaborated so far in this paper can be concluded that it is offering a contribution as small but extremely important regarding a topic in our country almost too little attention is as it is to identify and handling hazardous ingredients. The reason that the process of integration into the European Union requires work and commitment of all institutions within this dangerous substances treatment or general treatment of the environment is a nonnegotiable task or duty which in no way can neglect has affected much less to approach to this problem in the way that attracts the attention of the relevant authorities on this issue [5]. Another element that is important in the interior of this paper is that given the exact number of projects carried out so far. Reflected various theses and conclusions regarding the extent of environmental contamination in Kosovo are presented countries or companies with a high levels of hazardous ingredients. Presented accurate information about the current situation in our country with 
radioactive ingredients. It is worth mentioning that in this paper are highlighted factors that have contributed to this situation that we now have for example exploitation of millions of tons of lead and zinc mines Trepca and preparing their final product for domestic and international markets. Process refers to what has been said above that the situation which now has greatly helped even then structures negligence regarding the treatment of hazardous substances, that is actually working very little or nothing in terms of protection environment.

\section{References}

[1] Cena B, An overview of the radioactive waste in Kosovo, Journal of Chemical Technology and Metallurgy, 55(2), 2020, 404-408

[2] Cena B, Kostandin Dollani, Fundamental Principles of radioaktive waste managment in Kosovo, Scientific Works of the Union of Scientists, Plovdiv, XI, 2014, 150-155

[3] Radiation Protection Act, (Radprotact), Kosovo National Assembly, Official Journal , Pristina, Kosovo, 2011

[4] IAEA, International Atomic Energy Agency, Radiation Protection and Safety of Radiation Sources: International Basic Safety Standards, IAEA Safety Standards No. GSR (Interim), Vienna, Austria, 2011.

[5] Ravichandram R, Binukumar, Sreeram JP and Arukumar LS, An overview of radioactive disposal procedures of a nuclear medical department, J. of Med Phys., 32(6), 2011, 95-99

Received: January 18, 2021

Accepted: Februaty 23, 2021 